\title{
プレサルコペニア高齢者の歩行速度と身体機能・認知機能との関連 Relationships between Gait speed, Physical Functions and Cognitive Functions in elderly with pre-sarcopenia
}

\author{
森 耕平 ${ }^{1,2}$, 村田 伸 ${ }^{3}$, 白岩加代子 ${ }^{33}$, 安彦 鉄平 ${ }^{32}$, 岩瀬 弘明 ${ }^{4}$

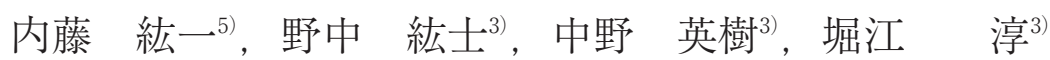

Kohei Mori ${ }^{1,22}$, Shin Murata ${ }^{3)}$ Kayoko Shiraiwa ${ }^{3)}$, Teppei Abiko ${ }^{3)}$, Hiroaki Iwase ${ }^{4}$

Koichi Naito ${ }^{5}$, Koji Nonaka ${ }^{3}$, Hideki Nakano ${ }^{3}$, Jun Horie ${ }^{3)}$

要旨：本研究の目的は, プレサルコペニア高齢者の歩行速度と身体機能および認知機能と の関連を検討することである。対象者を正常筋肉量群（48名）とプレサルコペニア群（17 名）の 2 群に分類し，歩行速度（通常 - 最速）と身体機能（膝伸展筋力，上体起こし，開 眼片足立ち時間，長座体前屈距離）および認知機能 (Mini-Mental State Examination, Trail making test-Part A; TMT-A）との相関分析を行った。その結果，プレサルコペニア群の 通常歩行速度と中程度以上の有意な相関が認められたのは, 膝伸展筋力 $(r=0.51)$ およ びTMT-A $(r=-0.52)$ であり，最速歩行速度では膝伸展筋力 $(r=0.74)$, TMT-A ( $r$ $=-0.66)$ および開眼片足立ち時間 $(r=0.56)$ であった。一方，正常筋肉量群の歩行速 度はいずれの項目とも中程度以上の有意な相関は認められなかった。これらの知見より， プレサルコペニア高齢者は正常筋肉量の高齢者に比べ努力性の高い歩行である可能性が示 され，下肢筋力，バランス能力および注意機能のわずかな低下をきっかけに歩行能力低下 を生じる可能性が示唆された。

キーワード：プレサルコペニア, 高齢者, 歩行速度, Trail making test

Abstract: The objective of this study was to analyze the association between gait speed and physical function as well as cognitive function in elderly individuals with presarcopenia. Subjects were divided into the normal muscle mass group $(n=48)$ and the presarcopenia group $(n=17)$. We performed a correlation analysis of gait speed (usual/maximum gait speed) with physical function (knee extension strength, sitting-up, one-leg standing time with eyes open, and sit-and-reach distance) and cognitive function (Mini-Mental State Examination and Trail making test-Part A [TMT-A]). The results showed moderate or higher significant correlations of usual gait speed with knee extension strength $(\mathrm{r}=0.51)$ and the TMT-A $(\mathrm{r}=-0.52)$. Maximum gait speed was correlated with knee extension strength $(r=0.74)$, TMT-A score $(r=-0.66)$, and one-leg standing time with eyes open value $(r=0.56)$ in the pre-sarcopenia group. In contrast, in the normal muscle mass group, no moderate or higher significant correlations between gait speed and any of the items were observed. These findings indicated that elderly individuals with pre-sarcopenia may walk with a higher level of exertion than those with normal muscle mass; this finding implies that a slight decrease in leg strength, balance ability, or attention function may trigger a decrease in walking ability of elderly individuals with pre-sarcopenia.

Key words: pre-sarcopenia, elderly,gait speed, trail making test

受付日：2019年 2 月22日, 採択日：2019年 3 月20日

京都粡大学大学院 健康科学研究科

Graduate School of Health Sciences, Kyoto Tachibana University

2) 関西福祉科学大学 保健医療学部：=582-0026 大阪府柏原市旭ヶ丘 3-11- 1 Phone：072-978-0088 Fax：072-978-0377

E-mail: morikouhei1@gmail.com

Faculty of Allied Health Sciences, Kansai University of Welfare sciences, 3-11-1 Asahigaoka, Kashiwara-city, Osaka, 582-0026, Japan Phone: 072-978-0088

3) 京都橘大学 健康科学部

Faculty of Health Science, Kyoto Tachibana University

神戸国際大学 リハビリテーション学部

Faculty of Rehabilitation, Kobe International University

白鳳短期大学 総合人間学科

Department of Physical therapy, Hakuho College 


\section{I 。緒 言}

高齢者の自立した生活や健康寿命の延伸, Quality of lifeの向上には歩行能力の維持・向上が必要不可欠で ある1)。この歩行能力の評価には, 高龄者の運動機能 を代表する指標 ${ }^{2}$ とされる歩行速度が主に用いられて いる。加龄による歩行速度の低下は，60歳を超えると 加速し, 高齢になるほどその低下率は大きくなる また, Studenski ら ${ }^{5)}$ は, 約 35,000 人の高齢者を平均 12 年間追跡調査し, 歩行速度が $0.1 \mathrm{~m} / \mathrm{s}$ 上昇するごと に死亡リスクが $12 \%$ 低下すると報告しており, 生命予 後との関連が指摘されている。

近年，高齢化が加速するわが国において，高龃者の 虚弱の中核病態であるサルコペニア ${ }^{6,7)}$ を予防すること の重要性が指摘されている。サルコペニアは筋肉量減 少を必須項目とし, 筋力低下, 身体機能低下（歩行速 度低下）の 3 つの要因から判定するというコンセンサ スレポートが，2010年にヨーロッパ8)，2014年にはア ジア ${ }^{9}$ から報告されている。また, その重症度は筋肉 量減少のみをプレサルコペニア, 筋肉量減少に筋力低 下あるいは歩行速度低下が加わるとサルコペニア，3 つの要因すべてが認められる場合を重度サルコペニア と階層的に分類される ${ }^{8)}$ 。サルコペニアの段階で認め られる歩行速度低下は, 将来の生活機能低下や生命予

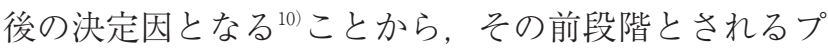
レサルコペニアから予防的介入を行い, 歩行能力を維 持することは高龃者の健康支援において極めて重要な 課題と考えられる。

高齢者の歩行速度の低下には, 様々な要因が関与す ることが報告されている。身体機能においては，膝伸 展筋力の低下 ${ }^{11,12)}$, 足趾把持力の低下 ${ }^{13,14)}$, バランス 能力の低下 ${ }^{14,15)}$ などとの関連が挙げられる。また, 身 体機能以外との関連も報告されており，認知機能障害 を有する高齢者は歩行速度の有意な低下を認める ${ }^{16)}$ とや, 注意機能の低下が二重課題条件下の歩行速度低 下と関連する ${ }^{17)}$ といった認知機能との関連も報告され ている。しかしながら，プレサルコペニア高齢者の歩 行速度と身体機能, 認知機能との関連を総合的に検討 した先行研究は見当たらない。このことが明らかにな れば，プレサルコペニア高齢者の歩行能力を維持およ び改善するための介入方法を検討する一つの資料にな ると考えられる。

そこで本研究は, 筋肉量減少を生じたプレサルコペ ニア高齢者の歩行速度と身体機能 - 認知機能との関連 を検討することを目的とした。

\section{II. 対象と方法}

\section{1. 対 象}

対象は，地域の高齢者交流事業に参加登録している 高齢者のうち，平成 29 年 9 月に実施された体力測定会 へ参加し, 歩行機能評価が行えた65歳以上の女性高歯令 者70名とした。

対象者には事前に測定内容や測定結果の取り扱いに ついて十分に説明し，書面にて同意を得たのちS 市の 保健師の立会いのもとで行った。なお，本研究は京都 橘大学研究倫理委員会の承認（承認番号17-14）を得 て実施した。

\section{2. プレサルコペニアの判定方法および歩行速度の 測定方法}

対象者の基本属性として年齢，身長，体重を収集し たのち，歩行速度，握力，四肢骨格筋指数（Skeletal Muscle Mass Index ; SMI) を用いてプレサルコペニ アの判定を行った。判定は, Asian Working Group for Sarcopenia (AWGS) ${ }^{9)}$ にる女性のサルコペニアの判 定基準（筋肉量低下：SMI5. $7 \mathrm{~kg} / \mathrm{m}^{2}$ 未満，筋力低下： 握力 $18 \mathrm{~kg}$ 未満, 身体機能低下: 通常歩行速度 $0.8 \mathrm{~m} /$ sec 以下）を基に，筋肉量が基準值以上である正常筋 肉量群 (48名) と, 筋肉量が基準值未満で握力および 通常歩行速度が基準值以上のプレサルコペニア群（17 名）の 2 群に分類した。なお，筋肉量が基準值以下で 握力または通常歩行速度が基準值以下のサルコペニア と判定された高齢者が 5 名いたが，本研究では分析対 象から除外した。よって, 本研究の分析対象者は65名 である。

歩行速度の測定には，アニマ株式会社製のシート型 足圧接地足跡計測装置ウォーク WayMW-1000を使用 した。歩行シートのサイズは長さ $2,400 \mathrm{~mm}$, 幅 $800 \mathrm{~mm}$ （センサーシート部 $600 \times 600 \mathrm{~mm}$, 厚さ $5 \mathrm{~mm}$ ) であ り，センサー空間分解能は $10 \times 10 \mathrm{~mm}$, 測定ポイント 数は14,000ポイントである。歩行課題は, シート前後 に $3 \mathrm{~m}$ の助走路と追走路を設けた歩行路を「いつも 通りの楽な速さで歩いてください」と指示を与えた通 常歩行と，「走らないで，できるだけ速く歩いてくだ さい」と指示を与えた最速歩行の 2 条件とした。本研 究では，シート上を歩行して得られたデータから，通 常および最速歩行速度（m/sec）を抽出して解析に用 いた。なお，プレサルコペニアの判定には通常歩行速 度を用いた。握力の測定には，デジタル式握力計（竹 井機器工業製，グリップ－D）を使用し，示指の第 2 
関節が直角になるように握り幅を調整した。両足を左 右に自然に開いて立ち，腕を自然に下げた状態で，握 力計が身体に触れないようにして最大努力で握るよう に指示した。測定は左右 2 回ずつ行い，それぞれの最 大值（kg）の平均を代表值とした。SMIの評価には, 生体電気インピーダンス法によるポータブル体成分分 析装置 InBody430（インボディ・ジャパン製）を用い, 測定により得られた四肢の骨格筋量（kg）を合計し， 身長 $(\mathrm{m})$ の 2 乗で除したSMI を算出した。

\section{3. 各種身体機能・認知機能の測定方法}

身体機能の評価は, 下肢筋力 (膝伸展筋力), 体幹 筋力 (上体起こし), バランス能力（開眼片足立ち時 間), 柔軟性（長座体前屈距離）を測定した。膝伸展 筋力の測定は, 加藤ら ${ }^{18}$ の方法に従って実施した。椅 子座位にて椅子の支柱にベルトを連結し，下腿下垂位 での等尺性筋力をハンドヘルドダイナモメーター（ア ニマ社製， $\mu$-Tas F-1）を使用して測定した。測定 の際は，被験者は両上肢を胸の前で組み，体幹垂直位， 膝関節は $90^{\circ}$ 屈曲位とし，センサーパッドは下腿遠位 部に接触させた。測定中はセンサーパッドのずれを防 止するために検者が前方で固定した。測定は左右 2 回 ずつ行い，それぞれの最大值（kgf）の平均を代表值 とした。膝伸展筋力は体重または下肢筋肉量等で補正 した值を用いることもあるが，Hairi ら ${ }^{199}$ は，補正し た筋力值よりも補正しない筋力值の方が日常生活活動 の制限や運動機能低下と関連したと報告しており，本 研究では膝伸展筋力の実測值を採用した。

上体起こしの測定は，マット上で仰臥位にて両膝関 節の角度を $90^{\circ}$ 屈曲位に保ち, 両腕を胸の前で組んだ 姿勢から, 両肘が両大腿部につくまで上体を起こすよ うに指示を与えた。30秒間にできるだけ多く繰り返し， その回数を測定した。

開眼片足立ち時間の測定は，裸足にて両手は体側に つけた状態で片足を上げた時から足が床に着くまでの 時間をデジタルストップウォッチで測定した。左右 2 回ずつ測定し，それぞれの最長時間（秒）の平均を代 表值とした。

長座体前屈距離の測定には, デジタル式長座体前屈 測定器（竹井機器工業製, デジタル長座体前屈計）を 使用した。壁に後頭部と腰背部をしっかりとつけ, 膝 関節を伸展した長座姿勢となり, 両肘関節は伸展位で 測定器に手を置いた。その後, できるだけ前方へ身体 を倒すように指示した。測定は 2 回行い, 最長距離 （cm）を代表值とした。

認知機能の評価には, Mini-Mental State Examination (MMSE) および注意機能の評価として Trail making test-Part A（TMT-A）を用いた。MMSE は全般 的な認知機能評価 ${ }^{200}$ として広く用いられており, 得点 範囲は 0 ３0点である。23/24点が認知症スクリーニ ングのカットオフとされている ${ }^{21}$ 。TMT-A は注意機 能の検査として信頼性と妥当性がすでに確認されてい る ${ }^{22,23)}$ 。方法は，紙面上にランダムに配置された $1 〜$ 25までの数字を小さい方から順に線で結ぶものであり, その所要時間（秒）を測定した。

\section{4. 統計学的解析法}

正常筋肉量群とプレサルコペニア群の基本属性，サ ルコペニア判定指標，身体機能，認知機能の比較には， 対応のないt検定を用いた。その後, 測定值の平均と 標準偏差から効果量（Cohen's d）を求めた。Cohen's $\mathrm{d}$ に打ける数值の解糔 ${ }^{24}$ は, 小さい>0.20, 中程度> 0.50 , 大きい $>0.80$ とした。また, 各群の通常歩行速 度・最速歩行速度と身体機能・認知機能との関連は Pearsonの積率相関係数を求めた。なお，本研究では 相関係数の絶対值0.4以上を相関ありと判定した ${ }^{25}$ 。 解析には統計解析ソフト SPSS22. 0 (IBM 社製) を用 い，有意水準は $5 \%$ とした。

\section{III. 結 果}

\section{1 . 正常筋肉量群とプレサルコペニア群の各測定項 目の比較}

分析対象者 65 名のうち, 正常筋肉量群に分類された のは48名，プレサルコペニア群に分類されたのは17名 であった。基本属性㧍よびサルコペニア判定指標にお いては, 体重 $(\mathrm{p}<0.01)$, SMI $(\mathrm{p}<0.01)$, 握力 $(\mathrm{p}$ $<0.01 ）$ に有意差が認められ，いずれの項目もプレサ ルコペニア群で低值を示した。それら有意差が認めら れた項目の効果量は, 体重 $(\mathrm{d}=1.25), \operatorname{SMI}(\mathrm{d}=2.13)$, 握力 $(\mathrm{d}=0.59)$ であった。一方, 年齢, 身長, 通常 歩行速度, 最速歩行速度には有意な差は認められな かった。

身体機能においては，上体起こし（ $\mathrm{p}<0.01 ） に の$ み有意差が認められ，プレサルコペニア群で低值を示

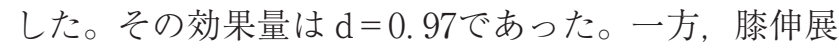
筋力, 長座体前屈距離, 開眼片脚立ち時間には 2 群間 に有意差は認められなかった。また，認知機能におい ては, MMSE およびTMT-A のいずれも有意差は認 
表 1 正常筋肉量群とプレサルコペニア群の各測定項目の比較

\begin{tabular}{|c|c|c|c|c|}
\hline & $\begin{array}{c}\text { 正常筋肉量群 } \\
\quad(\mathrm{n}=48)\end{array}$ & $\begin{array}{c}\text { プレサルコペニア群 } \\
(\mathrm{n}=17)\end{array}$ & $\mathrm{p}$ 值 & 効果量 \\
\hline 年齢（歳） & $71.88 \pm 3.56$ & $70.94 \pm 4.90$ & 0.40 & 0.24 \\
\hline 身長（cm） & $153.06 \pm 4.59$ & $151.46 \pm 6.13$ & 0.26 & 0.32 \\
\hline 体重（kg） & $54.07 \pm 7.06$ & $45.58 \pm 5.82$ & $<0.01$ & 1.25 \\
\hline $\mathrm{SMI}\left(\mathrm{kg} / \mathrm{m}^{2}\right)$ & $6.36 \pm 0.50$ & $5.39 \pm 0.28$ & $<0.01$ & 2.13 \\
\hline 握力 $(\mathrm{kg})$ & $23.08 \pm 3.62$ & $21.14 \pm 1.88$ & $<0.05$ & 0.59 \\
\hline 通常歩行速度（m/sec） & $1.36 \pm 0.20$ & $1.37 \pm 0.23$ & 0.82 & 0.06 \\
\hline 最速歩行速度（m/sec） & $1.83 \pm 0.23$ & $1.85 \pm 0.22$ & 0.76 & 0.09 \\
\hline 滕伸展筋力 (kgf) & $20.21 \pm 4.16$ & $18.76 \pm 3.41$ & 0.21 & 0.36 \\
\hline 上体起こし（回） & $9.16 \pm 6.07$ & $3.65 \pm 4.24$ & $<0.01$ & 0.97 \\
\hline 長座体前屈距離（cm） & $36.94 \pm 7.63$ & $33.06 \pm 8.24$ & 0.08 & 0.50 \\
\hline 開眼片脚立ち時間（秒） & $28.48 \pm 24.60$ & $28.56 \pm 27.55$ & 0.99 & 0.00 \\
\hline MMSE (点) & $28.67 \pm 1.59$ & $28.00 \pm 1.77$ & 0.15 & 0.41 \\
\hline TMT-A（秒） & $94.92 \pm 23.29$ & $102.76 \pm 34.01$ & 0.30 & 0.30 \\
\hline
\end{tabular}

SMI: Skeletal Muscle Mass Index, MMSE: Mini-Mental State Examination, TMT-A: Trail making test-Part A

められなかった（表 1$)$ 。

\section{2. 正常筋肉量群およびプレサルコペニア群の通常 歩行速度・最速歩行速度と身体機能・認知機能 との相関分析}

正常筋肉量群およびプレサルコペニア群における 通常歩行速度と身体機能・認知機能との相関係数を 表 2 に, 最速歩行速度と身体機能・認知機能との相 関係数を表 3 に示す。各群の通常歩行速度と相関係 数（絶対值） 0.4 以上の有意な相関を示した項目は, プレサルコペニア群の膝伸展筋力 $(\mathrm{r}=0.51), \mathrm{TMT}$ -A（ $r=-0.52 ）$ の 2 項目であった。一方, 正常筋 肉量群の通常歩行速度と相関係数 0.4 以上の有意な 相関を示す項目はなかった。

各群の最速歩行速度と相関係数（絶対值） 0.4 以 上の有意な相関を示した項目は，プレサルコペニア 群の膝伸展筋力 $(\mathrm{r}=0.74)$, 開眼片脚立ち時間 $(\mathrm{r}$ $=0.56)$, TMT-A $(r=-0.66)$ の 3 項目であった。 一方, 正常筋肉量群では相関係数 0.4 以上の有意な 相関を示す項目はなかった。

\section{IV. 考 察}

プレサルコペニアは, 筋力や身体機能 (歩行速度) の低下はないが, 筋肉量の減少のみを認める段階で あり, サルコペニアの前段階に位置づけられる9。 本研究対象者の測定項目を比較した結果, プレサル コペニア高齢者は筋肉量の指標である SMI の有意 な減少に加え, 筋力の指標である握力および上体起
こしに有意な低下を示したことから，正常な筋肉量の 高齢者に比べ，身体機能において虚弱な傾向を示すこ とが示唆された。

本研究では，プレサルコペニア高齢者と正常筋肉量 の高齢者における歩行速度と身体機能・認知機能との

表 2 通常歩行速度と身体機能・認知機能の相関分析

\begin{tabular}{lcccc}
\hline & $\begin{array}{c}\text { 正常筋肉量群 } \\
(\mathrm{n}=48)\end{array}$ & $\begin{array}{c}\text { プレサルコペニア群 } \\
(\mathrm{n}=17)\end{array}$ \\
\cline { 2 - 5 } & \multicolumn{2}{c}{ 通常歩行速度 } \\
相関係数 & $\mathrm{p}$ 值 & \multicolumn{2}{c}{ 通常歩行速度 } \\
相関係数 & $\mathrm{p}$ 值 \\
\hline 膝伸展筋力 & 0.27 & 0.08 & 0.51 & $<0.05$ \\
上体起こし & 0.14 & 0.38 & 0.12 & 0.66 \\
長座体前屈距離 & 0.14 & 0.35 & 0.12 & 0.65 \\
開眼片脚立ち時間 & 0.36 & $<0.05$ & 0.35 & 0.17 \\
$---M M S E$ & 0.10 & 0.51 & 0.03 & 0.90 \\
TMT-A & -0.27 & 0.06 & -0.52 & $<0.05$ \\
\hline
\end{tabular}

MMSE: Mini-Mental State Examination, TMT-A: Trail making test-Part A

表 3 最速歩行速度と身体機能・認知機能の相関分析

\begin{tabular}{lcccc}
\hline & $\begin{array}{c}\text { 正常筋肉量群 } \\
(\mathrm{n}=48)\end{array}$ & \multicolumn{2}{c}{$\begin{array}{c}\text { プレルコペニア群 } \\
(\mathrm{n}=17)\end{array}$} \\
\cline { 2 - 5 } & \multicolumn{2}{c}{$\begin{array}{c}\text { 最速歩行速度 } \\
\text { 相関係数 }\end{array}$} & $\begin{array}{c}\text { p 最速歩行速度 } \\
\text { 相関係数 }\end{array}$ & $\mathrm{p}$ 值 \\
\hline 膝伸展筋力 & 0.33 & $<0.05$ & 0.74 & $<0.01$ \\
上体起こし & 0.15 & 0.34 & -0.17 & 0.50 \\
長座体前屈距離 & 0.16 & 0.28 & 0.32 & 0.21 \\
開眼片脚立ち時間 & 0.39 & $<0.05$ & 0.56 & $<0.05$ \\
MMSE & 0.24 & 0.10 & 0.18 & 0.48 \\
TMT-A & -0.22 & 0.13 & -0.66 & $<0.01$ \\
\hline
\end{tabular}

MMSE: Mini-Mental State Examination, TMT-A: Trail making test-Part A 
関連を検討した。その結果，プレサルコペニア高齢者 の通常歩行速度には下肢筋力および注意機能が関連し， 最速歩行速度にはそれらに加えてバランス能力が関連 することが示された。一方，正常筋肉量の高齢者にお いては, 相関係数 0.4 以上の相関を示す項目は認めら れなかった。

高齢期における下肢筋力低下は, 将来の歩行能力低 下に影響を及ぼす要因 ${ }^{26)}$ とされ，歩行能力の維持に下 肢筋力は必要不可欠な機能である。下肢筋力の指標と した膝伸展筋力と歩行速度との関連については, 最速 歩行速度は膝伸展筋力と関連する ${ }^{11,27)} こ と ゙$ こ明らかで あるが, 通常歩行速度では膝伸展筋力との関連を認め ないとする報告 ${ }^{28,29)}$ が多い。この要因として, 最速歩 行時には通常歩行時と比べ下肢筋群に 2 倍前後の筋活

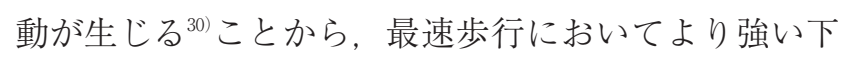
肢筋力の発揮が要求されるためであると考えられる。 本研究のプレサルコペニア高齢者では, 最速歩行速度 のみならず通常歩行速度でも膝伸展筋力との関連が認 められた。このことは, プレサルコペニア高齢者が少 ない筋肉量で相対的に大きな筋力の発揮が求められた 可能性があり, 通常歩行速度に抢いても努力性の歩行 を呈したものと推察した。また, 相関係数の絶対值が 正常筋肉量の高齢者に比ベプレサルコペニア高齢者で 明らかに高い值を示すことから，プレサルコペニア高 齢者の歩行速度はより筋力の影響を受けることが示唆 された。

またプレサルコペニア高齢者では，通常歩行速度お よび最速歩行速度と注意機能の指標としたTMT-A との間に有意な相関が認められた。すなわち, プレサ ルコペニア高齢者は, 注意機能が低下寸るほど歩行速 度が遅くなるという関係が示された。注意機能と歩行 との関係について, 辻井ら ${ }^{311}$ は, 高齢者の最速歩行速 度に影響を及ぼす要因として注意機能が抽出されたこ とを報告している。また，山田ら ${ }^{17)}$ や Hollman ら ${ }^{32}$ は， 注意機能の低下は二重課題条件下の歩行速度が低下す るだけでなく, 安定性の低下や不規則なリズムとなる ことを明らかにしている。特に, 歩行能力が低下した 高齢者ほど，歩行を行うこと自体に大きな注意が必要 になる ${ }^{17)}$ と考えられることから, 本研究で対象とした プレサルコペニア高齢者は, 歩行に対して大きな注意 配分が必要となり, 不安定な歩行状態である可能性が 示された。

さらに, プレサルコペニア高齢者の最速歩行速度と バランス能力との間に有意な正の相関が認められた。
歩行動作は, 重心を移動させながら片脚支持期と両脚 支持期を交代させ，力学的にはバランスが失われ，再 び元に戻ることが規則的に反復する現象 ${ }^{33}$ であること から，バランス能力は歩行の遂行に打いて重要な要因 と考えられる。先行研究においても, 歩行速度は開眼 片足立ち時間と関連する ${ }^{15}, 34$ ことが報告されており， 本研究のプレサルコペニア高齢者も先行研究の結果を 支持した。このことより，プレサルコペニア高齢者の 最速歩行は, バランス能力を必要とする不安定な歩行 であり，それを安定化させるために最速歩行速度とバ ランス能力との間に関連が認められたものと推察した。

一方, 正常筋肉量の高齢者においては, 通常歩行速 度と開眼片足立ち時間, 最速歩行速度と膝伸展筋力お よび開眼片足立ち時間とに弱い関連が認められたもの の, 相関係数 0.4 以上の関連を認める項目はなかった。 大杉ら ${ }^{34}$ は, 歩行動作は筋力やバランス能力などの 種々の身体機能と関連し，それぞれが複合的に機能す ることで行為が遂行されると述べている。言い換えれ ば, 本研究の正常な筋肉量を有する高齢者は, 個々の 機能のどれかに依存するのではなく，それぞれを効率 よく機能させて歩行動作を遂行しているため, いずれ の項目とも明らかな関連が認められなかったものと推 察した。

これらの知見より, プレサルコペニア高齢者の通常 歩行速度には下肢筋力および注意機能が関連し, 最速 歩行速度にはそれらに加えてバランス能力が関連する ことが示された。一方, 正常筋肉量の高齢者に扔いて は, 身体機能や認知機能の個々の機能との間に関連は 認められなかった。このことは, プレサルコペニア高 齢者は正常な筋肉量の高齢者に比べ, 努力性の高い歩 行である可能性が示され，プレサルコペニア高齢者が 心身機能のわずかな低下をきっかけに歩行能力低下を きたすリスクを有すると考えられた。ただし，本研究 の結果は女性高齢者のみを対象とした検討であり, 一 般化するためには男性高齢者も含めた検討が必要であ る。

\section{引用文献}

1）眞竹明宏, 三浦由紀子, 福元清剛：中高年女性の下肢筇群 の筋量抢上び筋力と歩行速度との関係. 山口県立大学看護 学部紀要, 2007, 11: 1- 6 .

2) Nagasaki H, Itoh H, Furuna T.: The structure underlying physical performance measures for older adults in the community. Aging Clin Exp Res, 1995, 7(6): 451-458.

3）杉浦美穂, 長崎浩, 古名丈人 - 他：地域高齢者の歩行能力. 
体力科学, 1998, 47(4)：443-452.

4) Kaneko M, Morimoto $Y$, Kimura M, et al: A kinematic analysis of walking and physical fitness testing in elderly women. Can J Spt Sci, 1991, 16(3): 223-228.

5) Studenski S, Perera S, Patel K, et al.: Gait speed and survival in older adults. Jama, 2011, 305(1): 50-58.

6) Fried LP, Tangen CM, Walston J, et al: Frailty in older adults: evidence for a phenotype. J Gerontol A Biol Sci Med Sci, 2001, 56(3): M 146-M 157.

7) Xue QL: The frailty syndrome: definition and natural history. Clin Geriatr Med, 2011, 27(1): 1-15.

8) Cruz-Jentoft AJ, Baeyens JP, Bauer JM, et al.: European consensus on definition and diagnosis: Report of the European Working Group on Sarcopenia in Older People. Age and Ageing, 2010, 39(4): 412-423.

9) Chen LK, Liu LK, Woo J, et al.: Sarcopenia in Asia: consensus report of the Asian Working Group for Sarcopenia. J Am Med Dir Assoc, 2014, 15(2): 95-101.

10) Furuna $T$, Nagasaki H, Nishizawa $S$, et al.: Longitudinal change in the physical performance of older adults in the community. J Jpn Phys Ther Assoc, 1998, 1(1): 1-5.

11）山崎裕司, 黒沢保寿, 山田純生 - 他 : 高齢患者の膝伸展筋 力と歩行速度, 独歩自立との関連. 総合リ八, 1998, 26 (7) : 689-692

12) Buchner DM, Larson EB, Wagner EH, et al.: Evidence for a non-linear relationship between leg strength and gait speed. Age and ageing, 1996, 25(5): 386-391.

13）金子諒, 藤澤真平, 佐々木誠. : 足趾把持筋力トレーニン グが最大速度歩行時の床反力に及ぼす影響. 理学療法科学, 2009, 24(3): 411-416.

14）池田望, 村田伸, 大田尾浩 - 他：地域在住女性高齢者の握 力と身体機能との関係. 理学療法科学, 2011, 26(2) : 255 - 258 .

15） $\mathrm{Wu} \mathrm{T}$ : 高齢女性の歩行能力と基礎的体力要因との関連. 広島大学大学院教育学研究科紀要. 第二部, 文化教育開発 関連領域, 2004, 52 : 279-286.

16) Auyeung TW, Kwok T, Lee J, et al.: Functional decline in cognitive impairment-the relationship between physical and cognitive function. Neuroepidemiology, 2008, 31(3): 167173.

17）山田実, 村田伸, 太田尾浩 - 他：高齢者における二重課題 条件下の歩行能力には注意機能が関与している. 理学療法 科学, 2008, 23(3) : 435-439.

18）加藤宗規, 山崎裕司, 柊幸伸 ·他 : ハンドヘルドダイナモ メーターによる等尺性膝伸展筋力の測定－固定用ベルトの 使用が検者間再現性に与える影響一。総合リハ, 2001，29 (11) : 1047-1050.

19) Hairi NN, Cumming RG, Naganathan V, et al.: Loss of muscle strength, mass (sarcopenia), and quality (specific force) and its relationship with functional limitation and physical disability: the Concord Health and Ageing in Men Project. J Am Geriatr Soc, 2010, 58(11): 2055-2062

20) Folstein M.: Mini-mental and son. Int J Geriatr Psych, 1998, 13(5): 290-294.
21) Cullen B, Fahy S, Cunningham CJ, et al:: Screening for dementia in an Irish community sample using MMSE: a comparison of norm-adjusted versus fixed cut-points. Int J Geriatr Psych, 2005, 20(4): 371-376.

22) Tombaugh TN: Trail Making Test A and B: normative data stratified by age and education. Arch Clin Neuropsych, 2004, 19(2): 203-214.

23) Heilbronner RL, Henry GK, Buck P, et al.: Lateralized brain damage and performance on trail making $\mathrm{A}$ and $\mathrm{B}$, digit span forward and backward, and TPT memory and location. Arch Clin Neuropsych, 1991, 6(4): 251-258.

24）水本篤, 竹内理 : 効果量と検定力分析入門一統計的検定を 正しく使うために一. 外国語教育メディア学会 (LET) 関西支部メソドロジー研究部会2010年度報告論集, 2010 : 47-73.

25）渡辺和之, 菊地臣一, 紺野愼一 - 他 : 整形外科患者に対す る精神医学的問題評価のための簡易質問表 (BS-POP) 一 妥当性の検討. 臨床整形外科, 2005, 40(7)：745-751.

26) Rantanen T, Guralnik JM, Ferrucci L, et al.: Coimpairments as predictors of severe walking disability in older women. J Am Geriatr Soc, 2001, 49(1): 21-27.

27）村田伸, 大田尾浩, 村田潤・他：虚弱高齢者における Timed Up and Go Test, 歩行速度, 下肢機能との関連. 理学療法科学, 2010, 25(4) : 513-516.

28) Burnfield JM, Josephson KR, Powers CM, et al.: The influence of lower extremity joint torque on gait characteristics in elderly men. Arch Phys Med Rehab, 2000, 81(9): 11531157.

29) Judge JO, Underwood M, Gennosa T.: Exercise to improve gait velocity in older persons. Arch Phys Med Rehabil, 1993, 74(4): 400-406.

30）小澤実奈, 村田伸, 空場勝之 ·他：最適歩行と最速歩行中 の歩行パラメーターと下肢筋活動の比較. ヘルスプロモー ション理学療法研究, 2016, 5(4) : 179-183.

31）辻井優衣, 村尾太郎, 岩瀬弘明 - 他 : 地域在住女性高齢者 の最速歩行時の歩行パラメータと身体機能との関連. ヘル スプロモーション理学療法研究, 2018, 8(2)：65-70.

32) Hollman JH, Kovash FM, Kubik JJ, et al.: Age-related difference in stride-to-stride variability during dual task walking: a pilot study. J Geriatr Phys Ther, 2004, 27(3): 83-87.

33）中村隆一, 斎藤宏, 長崎浩：基礎運動学第 6 版補訂. 医歯 薬出版, 東京, 2012:379-439.

34）大杉紘徳, 村田伸, 堀江淳 - 他 : 地域在住高齢者の各種歩 行パラメータに関連する要因分析. ヘルスプロモーション 理学療法研究, 2014, 4(1) : 31-35. 